\title{
RE-ORIENTING THE MALE GAZE AND SUBVERSION OF GENDER ROLES IN DELARIVIER MANLEY'S THE ROYAL MISCHIEF
}

\author{
Delarivier Manley'in The Royal Mischief Oyununda Erkek Bakışının Yeniden \\ Şekillendirilmesi ve Cinsiyet Rollerinin Tersine Çevrilmesi
}

\section{Volkan KILIÇ*}

\section{ABSTRACT}

Women's professional involvement in drama dates back to the restoration period in England, during which female dramatists emerged in English drama both as playwrights and actresses. The plays written by the female dramatists included mostly domestic issues, modesty, obedience, and chastity in the early restoration period, following the traits of the patriarchal authors depicting women within the limits of female virtue. Aphra Behn emerged as one of the most important and well-known dramatists of her period, who later encouraged a group of female dramatists, including Delarivier Manley, Catherine Trotter, and Mary Pix. These dramatists demonstrated female solidarity and contributed to each other's writing, giving way to the rise of the early feminist drama in England through their plays on the question of women and their conditions in the society, challenging the patriarchal discourse. They also adopted a more radical voice sometimes by subverting the established gender roles and male gaze at times. Furthermore, these female dramatists mostly parodied and subverted traditional male libertinism as appeared in many of the restoration comedies and tragedies. Delarivier Manley, in this respect, wrote a series of plays in the direction of "proto-feminist" discourse and reversed the gender roles by giving voice to the female protagonists in her plays, especially in The Royal Mischief.

Keywords: Feminism, Delarivier Manley, the Royal Mischief, Restoration Drama, female gaze.

\section{öz}

Restorasyon dönemi İngiltere'si İngiliz toplumunda kültür ve edebiyat açısından yeni bir dönemi işaret etmektedir. Restorasyon dönemi İngiliz tiyatrosunda kadınlar ilk defa tiyatro sahnelerinde profesyonel olarak rol almanın yanı sıra tiyatro oyunları yazarak daha önce erkelere özgü bu alanda söz sahibi olmaya başlamışlardır. Fakat

\footnotetext{
* Asst. Prof. Dr., Hatay Mustafa Kemal University, Faculty of Arts and Sciences, Department of Western Languages and Literature, Hatay/Turkey. E-mail: volkankilic25@hotmail.com. ORCID ID: 0000-0001-8961-5519.
} 
kadın oyun yazarları tarafından yazılan bu oyunlar kadınlara özgü domestik konular ve kadınlara biçilen itaat, iffet ve sadakat rollerini benimsemişlerdir. Kadınların temsili bakımından ataerkil söylemleri devam ettirse de, 17. yüzyılın son döneminde Aphra Behn'i takip eden bazı kadın oyun yazarları daha çok feminist bakış açısıyla kadının ataerkil toplumdaki yeri ve konumu hususunda aykırı fikirler ve söylem içerisinde oyunlarını yazmışlardır. Yazılan bu oyunlarda daha önce erkek bakış açısıyla temsil edilen kadın bu kez bir kadın yazar gözüyle erkek egemen dünyaya başkaldıran ve onlara biçilen cinsiyet rollerini reddeden bir anlayışla sergilenmiştir. Delarivier Manley, the Royal Mischief adlı trajedisinde bu hususları yansıtarak, feminist bir bakış açısıyla oyunun başkarakterine erkek rolü yüklemiş ve daha önce erkek oyun yazarları tarafından sıklıkla sergilenen "erkeğin kadına bakışını" ve cinsiyet rollerini tersine çevirerek bu söylemleri bertaraf etmeyi amaçlamıştır. The Royal Mischief oyununda, bu bağlamda, Manley oyunun başkahramanı olan Homais'i erkek egemen dünyaya meydan okuyan güçlü bir kahraman olarak çizerek, bu anlamda ilk defa erotik arzu ve şehvetin erkeklere karşı bir kadın tarafından oluşumunu yansıtmaktadır.

Anahtar Sözcükler: Feminizm, Delarivier Manley, the Royal Mischief, Restorasyon Tiyatrosu, kadın bakışı.

\section{Introduction}

The Restoration period in England marked an innovation for drama, which was women's inclusion in theatre professionally not just as actresses but also as playwrights. Likewise, Stevenson points out that "the first significant group of English women to earn their livings by writing is that of the women playwrights of the Restoration period" (1992: 36). These women dramatists of the Restoration period were mostly from the middle class, but they did not have any role model to follow unlike the male dramatists. Most of these dramatists' plays were performed on commercial public stage. However, as they appeared in theatrical scenes both as playwrights and actresses, the audience did not totally condemn the plays which were performed or written by these dramatists. According to Rubik (1998: 26) they were regarded as "eccentrics". One of the first dramatists to have a play acted on public stage was Katherine Philips, who wrote about domestic issues, female chastity and modesty. It has been stated that Katherine Philips's plays were regarded as amateurish and domestic; however, they did not include feminist issues by not defending women's rights both socially and politically. Katherine Philips, instead, followed the representation of traditional and conventional gender ideology and norms in her plays. In this respect, Philips was accepted and welcomed by the English literary 
circle, because she presented no threat to male dominated society as she adopted domesticity in her plays (Rubik, 1998).

However, such a literary atmosphere changed with Aphra Behn's entrance to the theatrical arena as she wrote socio-political plays, defending the rights of women. Beginning with Aphra Behn, those women dramatists attempted to give a public voice to their female heroines, revising, legitimizing, and transgressing tragedy conventions and generic structure. In this regard, the second half of the seventeenth century also witnessed the inauguration of women's rights for the first time due to the enlightenment philosophy, stressing individual rights and liberty with the rise of ideals of liberalism. Female dramatists in this period emerged to write against the patriarchal constructions of gender, which defined women "as angels or monsters, or either as maidens or "bitches"” (Karadaş, 2020: 386). Particularly, John Locke's Two Treatises of Government, which was published in 1689 , brought a revolution in re-evaluating the traditional values regarding the status of women because of the fact that the hard-core patriarchal views of the time depicted the inferiority of women in every respect of society. Locke's ideas gave rise to feminist awareness in the eighteenth century. According to Katherine Quinsey, the late seventeenth century "spans the shift from an earlier concept of gender as a variation in an essentially unified human nature to a hardening of gender categories, which theorized female as distinct in essence from male in all levels of existence - biological, spiritual, intellectual, and social." (1996: 1). This feminist awareness flowered the women's appearance on public space with literature, predominantly in drama, in the late seventeenth century. To some extent, this period was regarded as "culminating a process of ontological questioning of gender begun much earlier, and thus differing significantly from later eighteenth-century vindications of women's rights" (Quinsey, 1996: 1). Likewise, in line with Aphra Behn's feminist drama, the late seventeenth century became a critical period for women's awareness of their social rights.

\section{Analysis}

Delarivier Manley, Mary Pix, and Catherine Trotter were the other prominent women dramatists, following Aphra Behn, as they displayed female solidarity and contributed to each other's writing. Among these dramatists, Delarivier Manley was considered as the first professional English woman to support herself financially by writing and struggling to compete on equal terms with men. As Rubik claims, Delarivier Manley "modelled herself most 
closely on Behn's image, writing as 'scandalously' and sexually explicit her great predecessors" among these women playwrights of the Restoration period (1996: 60). Their plays mostly dealt with gender issues, while adhering to the literary trends and characteristics of Restoration drama, such as wittiness, sex, love, marriage, libertarianism, and political satire. They also parodied and subverted the traditional male libertinism as reflected in the Restoration comedies and tragedies. Moreover, these playwrights wrote both tragedies and comedies by following the prevailing tastes for heroic tragedy based on historical material, and comedy of London life based on Spanish intrigue (Shaw, 1998: 101).

Manley's The Royal Mischief gives prevalence to female characters, who are reflected as having sexual and political power. As Rubik points out, The Royal Mischief presents "control over language and sexual dynamism usually denied them in the plays of the time" (1996: 60). In her plays, accordingly, Delarivier Manley made use of these issues by adopting a feminist perspective, reversing the gender roles and giving an exceptional voice to the female protagonists. Furthermore, in Manley's play, the traditional male gaze of restoration plays was re-oriented and transformed into the female gaze, as the female protagonist is empowered whereas the male antagonists are emasculated and effeminized. In this respect, Delarivier Manley's The Royal Mischief can be considered as a subversive play in terms of adopting a woman's perspective by giving heroic voice to the erotic female desire, which was revolutionary in English drama. Therefore, this study aims at revealing Manley's The Royal Mischief as a subversive play in which the conventional male gaze is deconstructed as female gaze, since Homais adopts the masculine role of the traditional libertine figure of the Restoration plays, embracing female gaze to express her sexuality and bodily pleasures. Furthermore, Manley through Homais transgresses and subverts gender roles of her own period by making use of images of "manly woman" and "unmanly men". Manley in The Royal Mischief presents a female protagonist, Homais, who challenges the patriarchal society by making use of her sexuality, beauty, wit and attraction. Homais adopts the role of oriental Femme-Fatal, using her body and eyes even as a weapon. Manley in the play presents female characters as powerful heroines, depicting some feminist issues by exposing discrimination, prejudices and even violence against women. On the other hand, Manley in The Royal Mischief reveals the criticism of the destructive power of male sexuality in English society using 
an oriental setting, as she covers the question of women with an oriental veil.

The Royal Mischief is a play about the tragic consummation of forbidden love resulting from adulterous wives and husbands, which leads to their inevitable destruction in the end. As the title indicates, the play is centred on mischievous and wicked manners of the upper class and courtiers, as well as their disloyalty and unfaithfulness towards each other. It can be claimed that Manley criticizes both the English society through revealing, particularly, the corruption and rottenness of the courtly life of the English society. As in the play, Homais, the princess of Libardian, has fallen in love with Levan Dadian, the prince of Colchis and nephew of Homais's husband, the Prince of Libardian, though she has never met him. Early in the play, Homais sends her slave Acmat, a eunuch in her court or "harem", to persuade and lure Levan to come to her by attracting him with Homais's erotic portrait. They eventually declare their love and sexual desire. Then, they consummate their strong passion, describing each other as an erotic object. Thereafter, Levan realizes that his wife, Bassima, has fallen in love with Visier Osman. On the other hand, Homais designs a plan to get Levan by murdering Bassima and her husband. So, she secretly poisons Bassima. Seeing Bassima and Osman, Levan orders Osman to be killed. In the end, Prince of Libardian discovers the love between his wife, Homais, and his nephew, Prince of Colchis. He accidentally kills Homais with his stab, and Levan commits suicide by falling on his own sword. Consequently, the play has a tragic end with the death of the lovers. In the play, Manley made use of an oriental and exotic setting, such as Phasia and Colchis, situated in northwest Georgia. According to Derek Hughes (2001), Manley modelled the setting of the play on the book, The Travels of Sir John Chardin, which she probably encountered in her father's library as her father was a translator of travel writing Hughes (2001: 222) further points out that "Manley emphasises the oriental character of the plot by replacing the original Christian names with Muslim names". In this regard, the play can be classified as an oriental play in which Manley gives the exotic setting via the oriental characters and images.

Manley's strategy in the play is to write about a subversive counternarrative targeting the question of gender discrimination as well as the hypocrisy of the patriarchal ideology. Manley hence develops an embedded criticism and satire through constructing a counter-discourse to resist the masculine production of femininity (Richetti, 1999). For example, Homais's 
being imprisoned and locked up in her room can be considered as a reflection of the attitudes of the patriarchal society towards women, which Manley criticizes. As Andrea claims, along with The Royal Mischief, Manley "situates herself as a first feminist through emphasis on women's disabilities under patriarchy, a topic [she] pursued in her autobiographical writings, and her scandalous chronicles" (2007: 92). As reflected in the play, despite living in a patriarchal society, Homais as a woman follows her desire and sexual identity freely. She even crosses and exceeds the moral boundaries of society. However, Manley does not consider her to be an ideal female figure but Homais represents an uneducated and irrational female figure. It can be stated that in fact Manley criticizes Homais because she always follows her sexual desire throughout the play. Thus, it is a matter of education which Manley reflects as the double standards of English society, as women were deprived of the right of education. It is in this regard that Manley's female characters depict women as uneducated minds and morally corrupted. Manley also criticizes the patriarchal system which deprives women of their right of education. However, Manley believes that liberal education is required for women's moral as well as intellectual development. Accordingly, it can be stated that liberal education and gender equality in education are what the early eighteenth century feminists as well as the enlightenment philosophers defended. For example, Mary Wollstonecraft in her feminist treatise, A Vindication of the Rights of Women (1792) claimed that it is dangerous when a woman solely focuses on her external beauty and adornment. Instead, she should cultivate her reason and mind. For Batshua Makin, this is the indication of 'instrumental feminism', which underlines the significance of the education of women to develop their minds and souls. Similarly, Makin in Essay to Revive the Antient Education of Gentlewomen (1673) points out that,

custom, when it is inveterate, hath a mighty influence: it hath the force of Nature it self. The Barbarous custom to breed Women low, is grown general amongst us, and hath prevailed so far, that it is verily believed (especially amongst a sort of debauched Sots) that Women are not endued with such Reason, as Men; nor capable of improvement by Education, as they are. It is lookt upon as a monstrous thing; to pretend the contrary. A Learned Woman is thought to be a Comet, that bodes Mischief, when ever it appears. To offer to the World the liberal Education of Women is to deface the Image of God in Man, it will make Women so high, and men so low, 
like Fire in the House-top, it will set the whole world in a Flame (1997: 3).

Makin (1977) in this regard draws particular attention to the obligation of liberal education for women's mental and moral development. However, Manley emphasises in the play that women's longing for only external beauty is the indication of weakness and vanity. In this manner, in The Royal Mischief, Homais pursues only external beauty rather than education; thus she is presented by Manley as a morally corrupted woman lacking education and rationality, as one can find that her tragic death at the end is due to her strong desire and pursuit of sex. According to Bertucci, Manley "draws attention to issues of female education and sexual double standards, such as how women are fairly held to a higher-and perhaps unrealistic and even unhealthy - standard of self-control over the passion" (2017: 82). Bertucci also points out that Manley reflects "desire as a powerful and contagious force in order to emphasize the importance of a moral education for women that develops reason as a defense against the insidiousness of desires" (2017: 82). Manley, as a proto-feminist dramatist, hereafter presents and deals with the problem of woman in The Royal Mischief. In this respect, it can be claimed that Manley reveals desire and sexual pursuit of the characters as rather dangerous issues that devalue Homais's morality. Thus, Homais is refrained from a liberal education, which led her to be an uncontrollable woman only pursuing her passions and desire, causing her destruction and fall in the end. As Homais herself claims, "I'm a woman, made / Passionate by want of liberty" (Manley, 1981: 61). However, it is quite ironic that Homais's notion of liberty is only her sexual freedom rather than a demand for social and political liberty of a woman.

Conventional tragedies in general terms deal predominantly with the fall of tragic characters, among which the male ones are mainly considered as tragic heroes. Similarly, in Restoration drama such characterization continued, as particularly in Heroic tragedies or Heroic drama, the protagonists are mostly male. Moreover, most of the tragedies written by both male and even female dramatists confined females into a restricted size of roles, such as angelic, demonic, silenced, powerless, unseen, submissive, disobedient, and oppressed. Female characters are not given voice and they cannot dare to speak against their fathers, husbands, or brothers. However, The Royal Mischief differs from the tragedies of the Restoration period due to the fact that it was considered as a proto-feminist play, exposing a female self-expression, expressing female sexual desire, and challenging the 
dominant gender ideology and discourses. Manley subverts the generic conception of Restoration tragedies by representing her protagonist as a female heroine, giving voice to a female character. As a female heroine, for instance, Homais challenges and transgresses the patriarchal and puritanical notion of sexuality and femininity, which entails a strict obedience and submissiveness of women both in their private homes and in society. Manley's heroine Homais goes beyond and subverts the limits of the traditional notion of femininity of the period by embracing transgression, disobedience, defiance and breach against male oppression. Although Manley subverts and deconstructs the depiction of women, common in most of the Restoration tragedies, in which women who transgressed their gender norms both verbally and sexually are punished and condemned to death at the end, she adopted and made use of the generic conventions in terms of the tragic death of heroines or heroes. In this respect, in the play, Homais, as a heroine, is punished and killed by her husband for her adultery. Accordingly, Homais, who is portrayed both as the protagonist and the tragic heroine, makes a deadly mistake, even regarded as hubris, as she decides to challenge the morality of society by committing adultery, which causes her downfall in the end. Even as she is about to die, Homais refuses to be silenced, claiming that her husband Levan Dadian's impotency and sterility drove her to become an adulterous wife, saying "Thou dotard, impotent in all but mischief, / How coud'st thou hope, at such an age, to keep / A handsome wife?" ( $\mathrm{V}, \mathrm{i})$. Thus, Homais, speaking even in her last hours, can be regarded as a feminist manifesto for her challenge and rejection of fate for being a woman in a male-dominant society.

As in The Royal Mischief, Homais uses her eyes and beauty as a weapon instead of using her mind and reason, which can be severely criticized and opposed from any feminist stance. It can be stated that this supports only a patriarchal view that women lack irrationality and intellectual capacity. Hence, Homais, who seems to lack a liberal education, stressing the development of one's mind and soul, follows only bodily desires, using her eyes and physical attraction repeatedly to hunt the males around her. In this manner, it can be stated that the male gaze which is repeatedly represented in conventional plays becomes a female gaze in The Royal Mischief, in which Homais becomes both a spectacle and a spectator. Moreover, Levan becomes the object of desire for Homais, which can be regarded as the transgression of the male gaze into the female. This occurs when Homais sees the portrait of the prince, Levan Dadian, and she suddenly falls in love 
with him and bears a strong desire and passion towards him. In this sense, Homais acts like an aggravated Restoration libertine even to the extent that she sees herself as a masculine heroine, and love becomes a sort of battle for her, as she says "I'll push the bold adventure on, /And either die or conquer" (Manley, 1981: 58). Homais struggles for love, adopting a manly attitude and stance, and Acmat considers her as a hunter by stating, "prepare your charms, and let us see / What Wounds your Eyes can make" (Manley, 1981: 59). On the other hand, Homais's manly behaviour contradicts with Acmat, who is presented as the barren slave in the Harem, as Homais refers to her passivity, "thy barren Soul ne'er knew the growth of love" (Manley, 1981: 58). Ironically, Acmat praises only Homais's beauty and attraction, not her mind: "such Courage and such Beauty must make the universal/World your Slaves" (Manley, 1981: 58). Acmat here takes her sexual attraction for granted as her weapon to conquer the male world. In due course, it can be claimed that conquest as a term is not always associated with femininity but masculinity because of the fact that in the $17^{\text {th }}$ and $18^{\text {th }}$ century English society, femininity was described as the condition of passivity and obedience, not activity or women's inclusion in manly attributes. Rubik states in this manner that "Homais really usurps the male privilege of singling out her quarry and pursuing him; she herself is the aggressor and rejects the traditional idea that the female body is a reward for courtship" (1996: 170). On the other hand, there is the notion that, unlike men, women should conceal their sexual desires in society, which is considered as virtue and chastity. Homais exceeds this notion by rejecting and concealing her sexual appetite and desire for bodily pleasure. Therefore, it is clear that Homais adopts a masculine stance by re-orienting the male gaze and transgressing the gender roles by being empowered by the de-powered male characters. This can be regarded as a challenge and criticism against the established morality and the puritan view of gender roles, which requires women to be obedient, chaste and suppression of passion.

Furthermore, in many of the Restoration plays, it was a tradition for the male protagonists to have a male gaze towards the females in an erotic manner, stipulated as Restoration libertinism, where the female characters are exposed to male gaze. In like manner, male libertinism was widespread in many of the Restoration plays, particularly in Restoration comedies, which can directly be linked to a male gaze by male libertines, used principally by the male dramatists, with the exception of John Dryden and Sir John Etherege. Female libertinism, on the other hand, emerged during the Resto- 
ration period with the first appearance of female dramatists in English theatres, including Aphra Behn, Catharina Trotter, Mary Pix, and Delarivier Manley, who used female libertines in their plays primarily as female heroines. Moreover, in contrast to such restoration plays, Delarivier Manley's The Royal Mischief includes a female libertine, Homais, who gazes at Levan and sexually objectifies him. Accordingly, it can be stated that Levan is subjected to a female gaze, and he is described by Homais and Acmat as brave, handsome, and attractive. Likewise, Levan is the Prince of Colchis, married to Selima but falls in love with his uncle's wife, Homais then. Contrary to Homais's sexually energetic, desirous, active, and adulterous personality, Levan is a bit shy, having the fear of adultery and the immorality of forbidden love. However, when he encounters her, he takes a fancy to Homais's irresistible attraction and sexuality and desperately falls in love with her. The play is centred around the power of a female gaze, as in the case of Homais, attracting, objectifying and manipulating the males with her eyes, which are described as powerful and effective magnets to attract anybody. Acmat describes Homais:

Impossible, you know not half your Power,

Those Eyes did never vainly shoot a Dart,

Such are their Fires, so sparkling, so attractive,

So passionately, soft and tender,

So full of that desire they give, as though

The Glorious Heaven stood ready for Possession:

You never look but to command our love,

And give your Lover hope- (Manley, 1981: 56).

Acmat emphasizes the attraction of Homais's eyes even further, saying, "Prepare your charms, and let us see/What Wounds your Eyes can make" (Manley, 1981: 59). Homais is a hunter who uses her eyes and beauty to attract men around her. Hence, Homais's eyes resembled a shotgun wounding people, and she is hunting men. On the other hand, Homais's husband finalizes the play by accusing Homais of using her erotic sight and sexual eyes, which leads to the tragic death of the males around her. So he says, "What mischief two fair guilty eyes have wrought, / Let lovers all look here, and shun the dotage./ To Heaven my dismal thoughts shall straight be turned, / And all these sad disasters truly mourned" (Manley, 1981: 103). In this respect, from the beginning to the end of the play, the image of eyes for Homais stands as a powerful force and dynamic within the central action of the play, since Homais's eyes become a destructive force for sexual 
desire. In this respect, it can be stated that Homais's eyes depict the power of women and remain as an attractive female gaze.

Manley in The Royal Mischief challenges and reverses the gender roles of the Restoration Drama because, contrary to the traditional Restoration plays, which involve mostly a male libertine who is playful and sexually objectifies women around him, in The Royal Mischief there is a female libertine, Homais, who cuckolds her husband. Levan is portrayed as an effeminate man because when he sees Homais, he faints and falls at her feet, which is believed to be a female attitude and nature. He is also a jealous husband who is willing to kill his wife's alleged lover. Obviously, Homais's sexual desire comes out of her husband's impotency, who cannot fulfil his duty as a husband, thus having a distinctive jealous nature by even imprisoning and locking Homais up in the Harem room. It is in this regard that The Royal Mischief reflects impotent and inactive males in contrast to active and potent females. Acmat is the slave of Homais, who acts as a confidante to Homais throughout the play. He is a eunuch in the Royal Apartment, which is the Harem of the court. He mediates between Homais and Levan. He is also one of the effeminate male characters in the play. Moreover, he sees himself as a woman, and identifies himself with the female sex. Ismael is the other character who is confidant to Osman in the play. However, Manley presents Homais as a woman more masculine or heroic than the male characters. Comparing her with Levan, she is braver and more courageous. Similarly, Derek Hughes points out that "Homais, who will 'either die or conquer' and whose lust can only 'with possession be abas'd, assumes the position and rhetoric of a Restoration libertine vis-à-vis the feminised Levan, who faints at her feet, and her ex-lover Ismael, whom she spurns as a rake would discard his former mistress" (2011: 35). As a powerful female heroine, Homais struggles against patriarchal oppressions, mostly by her husband, the Prince of Libardian. Since she is physically attractive and appealing lady, she remains subjected to the male gaze and portrayed as an erotic and lustful object both by Levan and Acmat. In Act II of the play, Acmat describes her as an erotic object:

How often have I seen this Lovely Venus,

Naked, extended, in the gaudy Bed,

Her snowy Breasts all panting with desire,

With gazing, melting Eyes, survey your Form,

And wish in vain, it had life to fill her Arms. (Manley, 1981: 72). 
Acmat continues depicting Homais through erotic images and descriptions in the play. Homais is "the Virgin Fruit, as yet untouchable" (Manley, 1981: 73), due to her husband's impotency. Homais uses such erotic expressions as well:

What to conceal desire, when every

Attom of me trembles with it, I'll strip

My Passion naked of such Guile, lay it

Undrest, and panting at his feet, then try

If all his temper can resist it. (Manley, 1981: 75).

In a way, Homais, locked and imprisoned by her husband, adopts a feminist voice asking for liberty and sexual freedom. For example, as she says, “...l'm a Woman, made / Passionate by want of Liberty" (Manley, 1981: 61). Fighting for the sake of this, she rejects submitting herself to the patriarchal authority.

\section{Conclusion}

To conclude, The Royal Mischief is considered as a subversive play, adopting a woman's perspective by giving voice to the erotic female desire. It is evident in The Royal Mischief that Manley, as a proto feminist dramatist, depicts a female protagonist, Homais, who adopts the role of male libertinism of the Restoration plays since she challenges the patriarchal society with her sexuality, beauty, wit and attraction. Homais uses her female sexuality, which can be regarded as a weapon of a woman, adopting the role of oriental Femme-Fatal. In this respect, by presenting female characters as heroines in The Royal Mischief, Manley deals with feminist issues such as the hypocrisy of the patriarchal society, sexual discrimination, prejudices and violence against women. Manley, accordingly, adopts a feminist perspective, through the reconstruction of gender roles, giving exceptional voice to a female protagonist in The Royal Mischief. The present study proves that the male gaze in traditional restoration plays is deconstructed as the female gaze, in which Homais is empowered while the male antagonists are emasculated and effeminized. Respectively, The Royal Mischief can be read as a subversive play in which Homais adopts a female gaze in order to express her sexuality and bodily pleasures. Manley, subsequently, reveals a feminist criticism of the destructive power of male sexuality in English society as she covers the question of women with an oriental veil in The Royal Mischief. Consequently, Manley subverts the traditional gender roles and makes use of images of "manly women" and "unmanly men". 


\section{References}

Andrea, Bernadette (2007). Women and Islam in Early Modern English Literature. Cambridge: Cambridge University Press.

Ballaster, Rosalind (Ed.). (1992). "Introduction”. New Atlantis. By Delarivier Manley. New York: New York UP, v-xxv.

Bertucci, Christopher (2017). "Contagious Desire as Feminist Satire in Delarivier Manley's The Royal Mischief”. Restoration Studies in English Literary Culture, 1660-1700, 41(1): 81-99.

Hughes, Derek (2001). "General Introduction". Eighteenth Century Women Playwrights, Vol 1. Eds. Margarete Rubik \& Eva Zettelmann. London: Pickering.

Karadaş, Fırat (2020). “Aphra Behn'in 'Çapkın Denizci' ve Sadık Şendil'in 'Kanlı Nigar' Oyunlarında Ataerkil Sistemin Cinsiyet Etiketlerini Bozan Kadın Portreleri”. Gaziantep Üniversitesi Sosyal Bilimler Dergisi, 19(2): 385-402.

Makin, Batshua (1673). "An Essay to Revive the Ancient Education of Gentlewomen”. The Female Spectator: English Women Writers before 1800. (1977). Eds. Mary R. Mahl \& Helene Koon. Bloomington and London: Indiana University Press.

Manley, Delarivier (2001). The Royal Mischief. Eighteenth Century Women Playwrights, Vol 1. Eds. Margarete Rubik \& Eva Zettelmann. London: Pickering, 51-103.

McDowell, Paula (1998). The Women of Grub Street: Press, Politics, and Gender in the London Literary Marketplace 1678-1730. New York: Oxford UP.

Merens, Rebecca (1996). "Unmanned with Thy Words: Regendering Tragedy in Manley and Trotter". Broken Boundaries: Women and Feminism in Restoration Drama. Ed. Katherine M. Quinsey. Kentucky: Kentucky UP, 31-53.

Parsons, Nicola (2003). "Secrecy and Enlightenment: Delarivier Manley's New Atalantis". Libertine Enlightenment: Sex Liberty and Licence in the Eighteenth Century. Eds. Peter Cryle \& Lisa O'Connell. New York: Palgrave Macmillan, 145-160.

Pearson, Jacqueline (1988). The Prostituted Muse: Images of Women and Women Dramatists, 1642-1737. New York: St. Martin's Press. 
Quinsey, Katherine M. (1996) "Introduction". Broken Boundaries: Women and Feminism in Restoration Drama. Ed. Katherine M. Quinsey. Kentucky: Kentucky UP.

Rogers, Katharine M. (1994). The Meridian Anthology of Restoration and Eighteenth Century Plays by Women. New York: Meridian.

Rubik, Margarete (1998). Early Women Dramatists 1550-1800. London: Macmillan.

Shattock, Joanne (1993). The Oxford Guide to British Women Writers. Oxford: Oxford UP.

Shaw, Marion (Ed.) (1998). An Introduction to Women's Writing. London: Prentice Hall.

Stevenson, Jane (1992). Women Writers in English Literature. Essex: Longman York Press.

The following statements are made in the framework of "COPE-Code of Conduct and Best Practices Guidelines for Journal Editors":

Ethics Committee Approval: Ethics committee approval is not required for this study.

Declaration of Conflicting Interests: The author has no potential conflict of interest regarding research, authorship or publication of this article. 